\title{
Endoscopic mucosal resection of inflammatory fibroid polyp in the transverse colon
}

A 70-year-old woman visited our hospital complaining of anemia. Laboratory testing revealed a peripheral blood hemoglobin concentration of $9.4 \mathrm{~g} / \mathrm{dL}$. Upper and lower gastrointestinal endoscopic examinations were performed to investigate the cause of the anemia. The findings of the upper endoscopic examination were normal. However, the lower endoscopic examination revealed a semipedunculated polyp with a flat elevated lesion in the transverse colon ( Fig. 1). The surface of the broad-based polyp was erythematous and eroded. The pathological analysis of the biopsy specimen from the polyp suggested inflammatory fibroid polyp (IFP). It was considered that the polyp was the cause of the anemia and that excision was therefore indicated.

The polyp was resected by the endoscopic mucosal resection (EMR) technique, with injection of physiologic saline solution into the submucosal layer followed by clipping. The resected specimen measured $20 \times 10 \times 10 \mathrm{~mm}$. The cut surface was whitish ( $\bullet$ Fig. 2). Histologically the polyp consisted of loosely structured fibroblastic tissue composed of fibroblastic cells intermingled with numerous inflammatory cells. The fibroblasts were vaguely arranged in a whorl structure, and the inflammatory cells consisted of eosinophils, lymphocytes, and plasma cells ( $\mathbf{F i g . 3 a}$ ). Erosion was observed on the surface of the polyp ( Fig.3b). These features were compatible with the diagnosis of IFP. After removal of the polyp, the patient's anemia was alleviated.

With regard to pathogenesis and etiology, it has been recently proposed that IFP is caused by an allergic reaction to bacterial, chemical, traumatic, and/or neurogenic stimuli, or is a reactive lesion of fibroblastic or myofibroblastic nature [1,2]. Over the past decades, surgical excision has been the main treatment of choice for colonic IFPs, because of their relatively large size and the difficulty of differentiating them from malignant polyps endoscopically or even pathologically. If, however, the diagnosis of IFP is confirmed, polyps of the large intestine can best be removed endoscopically as they are clinically and histologically benign [3]. Based on a literature review, six cases of colonic

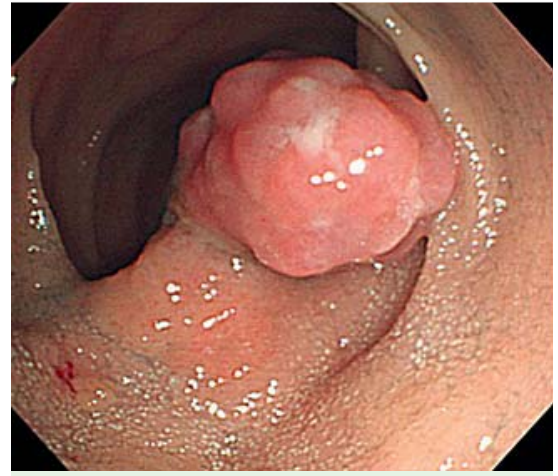

Fig. 1 The lower endoscopic examination revealed a semipedunculated polyp with flat elevated lesion in the transverse colon.

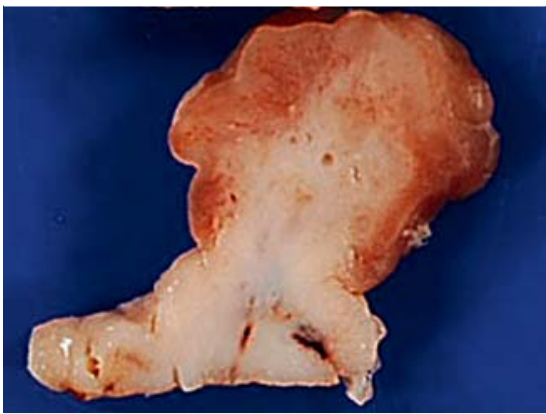

Fig. 2 The resected specimen measured $20 \times 10 \times 10 \mathrm{~mm}$ in size. The cut surface was whitish.

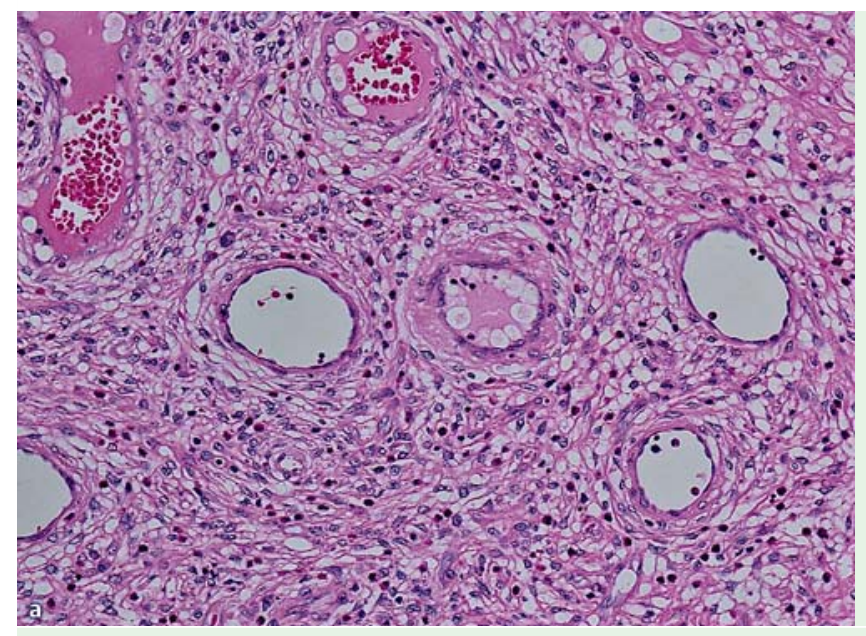

Fig. 3 a Histologically the polyp consisted of loosely structured fibroblastic tissue composed of fibroblastic cells intermingled with numerous inflammatory cells. The fibroblasts were vaguely arranged in a whorl structure, and the inflammatory cells consisted of eosinophils, lymphocytes, and plasma cells. b Erosion was observed on the surface of the polyp.

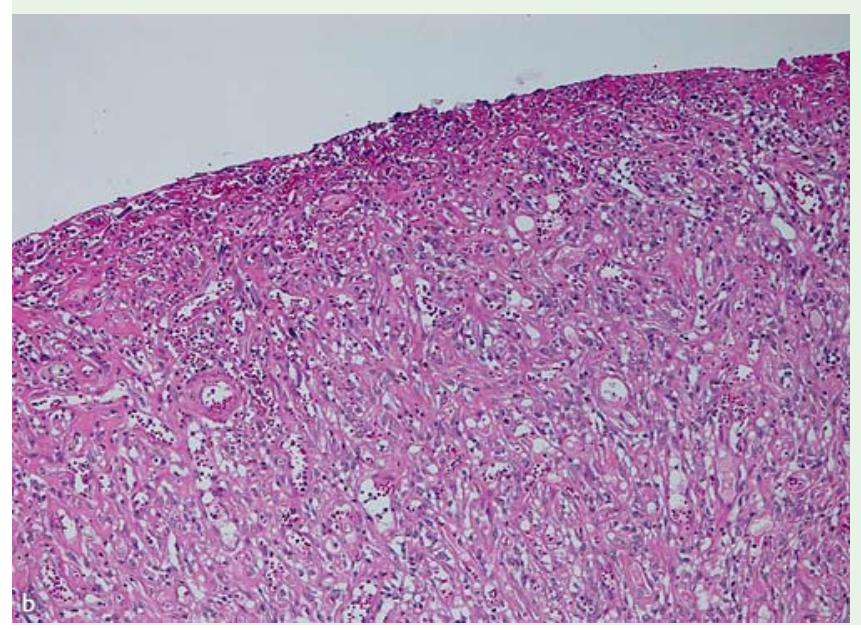

IFP treated by endoscopic resection including the present case are summarized in Table 1 [3,4-7]. Our case is the first reported case of a large, broad-based, semipedunculated-type IFP where EMR was performed successfully. EMR may be the treatment of a choice even in large pedunculated and semipedunculated polyps with a thick stalk. 
Table 1 Summary of colonic inflammatory fibroid polyps treated by endoscopic resection

\begin{tabular}{|c|c|c|c|c|c|c|}
\hline Authors & Year & $\begin{array}{l}\text { Patient age } \\
\text { and sex }\end{array}$ & $\begin{array}{l}\text { Polyp } \\
\text { location }\end{array}$ & $\begin{array}{l}\text { Polyp size, } \\
\text { mm }\end{array}$ & Gross appearance of polyp & Resection method \\
\hline Niv and Hurwitz [3] & 1985 & $71 \mathrm{M}$ & Cecum & 40 & Pedunculated & Polypectomy \\
\hline Nakase et al. [4] & 2000 & $45 \mathrm{~F}$ & Cecum & 5 & Sessile & EMR \\
\hline Sakamoto et al. [5] & 2005 & $40 \mathrm{M}$ & Asc. & 35 & Pedunculated & Polypectomy \\
\hline Park et al. [6] & 2007 & $28 \mathrm{M}$ & Sig. & 40 & Pedunculated & Polypectomy \\
\hline Kim et al. [7] & 2008 & $23 \mathrm{~F}$ & Des. & 45 & Pedunculated & Polypectomy \\
\hline Present case & & $70 \mathrm{~F}$ & Trans. & 20 & Semipedunculated & EMR \\
\hline
\end{tabular}

M, male; F, female; Asc., ascending colon; Sig., sigmoid colon; Des., descending colon; Trans., transverse colon; EMR, endoscopic mucosal resection.

\section{Endoscopy_UCTN_Code_TTT_1AQ_2AD}

\section{Competing interests: None}

\section{H. Ishibashi, ${ }^{1,2}$, K. Aoyagi ${ }^{2}$, H. Koba- yashi $^{1}$, K. Kurahara ${ }^{1}$, K. Kominato ${ }^{1}$, K. Kawasaki ${ }^{1}$, Y. Oshiro ${ }^{3}$, T. Fuchigami ${ }^{1}$}

${ }^{1}$ Institute of Gastroenterology, Matsuyama Red Cross Hospital, Matsuyama, Japan

2 Department of Gastroenterology and Medicine, Fukuoka University School of Medicine, Fukuoka, Japan

${ }^{3}$ Department of Pathology, Matsuyama Red Cross Hospital, Matsuyama, Japan

\section{References}

1 Goldmann RL, Friedmann NB. Neurogenic nature of so-called inflammatory fibroid polyps of the stomach. Cancer 1967; 20: $134-143$

2 Widgren S, Pizzolato GP. Inflammatory fibroid polyp of the gastrointestinal tract: possible origin in myofibroblasts? A study of twelve cases. Ann Pathol 1987; 7: $184-$ 192

3 Niv Y, Hurwitz A. Inflammatory fibroid polyp of the cecum, associated with adenomatous polyp and ovarian thecoma. Isr J Med Sci 1985; 21: 624-626

4 Nakase H, Mimura J, Kawasaki T et al. Endoscopic resection of small inflammatory fibroid polyp of the colon. Intern Med 2000; 39: $25-27$

5 Sakamoto T, Kato H, Okabe T et al. A large inflammatory fibroid polyp of the colon treated by endoclip-assisted endoscopic polypectomy: A case report. Dig Liver Dis 2005; 37: 968-972

6 Park YB, Cheung DY, Kim JI et al. A large inflammatory fibroid polyp in the sigmoid colon treated by endoscopic resection. Intern Med 2007; 46: 1647-1649
7 Kim BC, Cheon JH, Lee SK et al. Needle knifeassisted endoscopic polypectomy for a large inflammatory fibroid colon polyp by making its stalk into an omega shape using an endoloop. Yonsei Med J 2008; 49: 680-686

\section{Bibliography}

Dol http://dx.doi.org/

10.1055/s-0031-1291499

Endoscopy 2012; 44: E15-E16

(c) Georg Thieme Verlag KC

Stuttgart · New York

ISSN 0013-726X

\section{Corresponding author}

\section{H. Ishibashi, MD}

Department of Gastroenterology and Medicine Fukuoka University School of Medicine

7-45-1 Nanakuma, Jonan-ku

Fukuoka 814-0180

Japan

Fax: +81-92-8742663

i-hide@peace.ocn.ne.jp 